\title{
Methods of oak silviculture in Austria
}

\author{
E Hochbichler \\ Universität für Bodenkultur, Institut für Forstökologie; Osterreichische Bundesforste Marxergasse 2, \\ A-1130, Vienna, Austria
}

(Received 6 January 1993; accepted 2 June 1993)

\begin{abstract}
Summary - In Austria oak stands occupy an area covering $\approx 150000$ ha or $\approx 4 \%$ of the total forest area. Half of the oak stands are managed as coppice or coppice with standards, and half are managed as high forest. During the last 2 decades there has been a remarkable increase in developing young oak stands. The interest in managing suitable forest areas for oak is apparently growing. Therefore regeneration methods, timely and proper management and thinning regimes will be very important in the near future. As a result of different growth performances it is necessary to determine different production targets and rotation cycles. For this reason treatment programmes have been developed dependent on selected sites considering biological, ecological and technical parameters to achieve high economic yield. Investigations into oak stands of different age classes have already shown the importance of timely cleaning, tending and continuous thinning during the first third of the rotation cycles. Various treatment programmes and practical knowledge relating to regeneration, tending, crop selection and thinning have been discussed.
\end{abstract}

\section{silviculture / oak / high forest system / coppice with standards / coppice}

Résumé - Méthodes de sylviculture du chêne en Autriche. La chênaie occupe en Autriche une superficie d'environ 150000 ha, soit près de $4 \%$ de la surface forestière totale. La moitié des peuplements de chênes est traitée en taillis ou taillis-sous-futaie, l'autre moitié est aménagée en futaie. Au cours des 2 dernières décennies, il y a eu un accroissement remarquable de création de jeunes peuplements de chênes. L'intérêt pour l'aménagement des stations favorables aux chênes est apparemment grandissant. Pour cette raison, les méthodes de régénération, époque, aménagement et régime des éclaircies, seront très importantes dans la prochaine période. En relation avec les différentes performances de croissance, il est nécessaire de définir différents niveaux de productivité et de durée de rotation. C'est pour ces raisons que des programmes d'aménagement ont été développés, en liaison avec les caractéristiques des stations, prenant en compte les paramètres biologiques, écologiques et techniques, cela afin d'aboutir à une production de haute valeur économique. Les recherches menées dans des peuplements de chêne de différentes classes d'âge mettent en évidence limportance de la période des dégagements et le rôle de la gestion des éclaircies au cours du premier tiers de la rotation. Différents types d'aménagement et les connaissances pratiques concernant la régénération, le régime des éclaircies, la sélection des tiges sont examinés. 


\section{INTRODUCTION}

In Austria high and production forests of oak stands (Quercus petraea and Quercus robur) cover 51000 ha. The most important trees in the oak-rich mixed forests are beech and hornbeam. 70000 ha belong to the "land-coppice system" and the coppice with the standard system and 25000 ha are part of coppice in the alluvial plains. In the overwood of these forests oak dominates by $65 \%$.

Oak stands are predominant in both large and small private forests. Due to the economic changes and increasing respect for the ecological interrelations in federal and private forests, over the last 2 decades, the following systems have been applied:

- increased planting of (mixed) oak stands;

- a more intensive tending and fostering of oaks in the oak-rich high forests and coppice with standards;

- an increasing change from coppice systems and/or coppice with a standards system with diffuse standards into overwoodrich coppice with standards system (high forest system).

The aim of these measures is to use the existing capacity of the sites more efficiently and to build up more stable mixed oak stands.

Due to the catastrophic infestation of the coppice with standard forests by the oak-mistletoe (Loranthus europaeus) in the eastern parts of Austria (Krapfenbauer, 1982; Mayer et al, 1982; Buchleitner, 1983) a more intensive study of these problems began. After heavy damage to the mixed beech forest sites in the lower alpine areas, where spruce and pine are still dominant, the establishment of mixed deciduous woods (oak stands) is becoming more important.
Large private forest enterprises have given the (high-quality) timber production of oak special attention. The abovementioned damage and a change in the silvicultural and economic potential for high-quality timber has led to a rethinking process.

Numerous examples show that the objective-oriented treatment of oak stands considering the growth potential of the site in the high forests as well as in the coppice with standards forests, presents an opportunity for the owners of small forests to meet a part of the production costs (Anonymous, 1987; Weilharter, 1991).

The coppice system has grown more important as a source of biomass energy.

On the one hand, one finds increasing silvicultural efforts to promote oak forests, and on the other one observes an alarming loss of vitality in oaks, which has been increasing and extending dramatically over the last couple of years.

\section{PRODUCTION OBJECTIVE - THE SILVICULTURAL SYSTEM}

Several sites are suitable for high-quality oak timber production: mixed deciduous forest sites in the alluvial plain regions, oak-rich beech forest sites and typical oak-hornbeam forest sites in the submontane regions (annual precipitation $\approx(600)$ $700-900 \mathrm{~mm}$, mean annual temperature $8-9^{\circ} \mathrm{C}$ ) and dry oak-hornbeam forest sites under Pannonic influence in the eastern part of Austria (annual precipitation of $\approx$ 450-700 mm, mean annual temperature $\left.8-10^{\circ} \mathrm{C}\right)$.

A major objective for the production of high-quality timber is the achievement of a diameter of $50(60) \mathrm{cm}$ with a regular annual ring structure, straight trunk and branch-free bottom logs. 
Different site factors cause a different term in growth (fig 1) and due to this different production periods and objectives are possible. With the decreasing quality of a

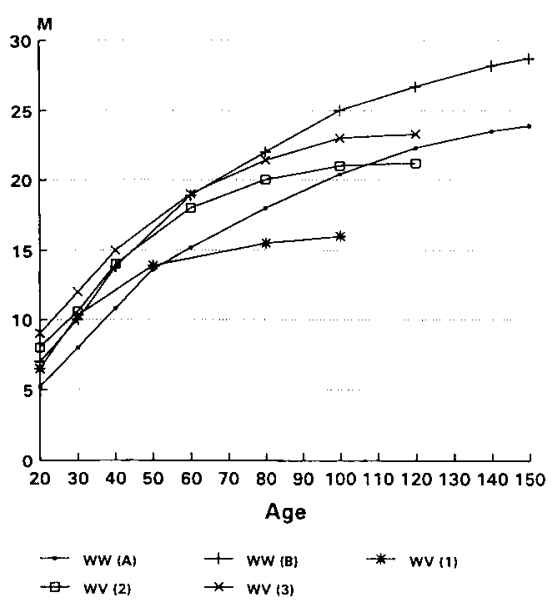

Fig 1. Development of the top-height of oaks in high forest in various regions $(A, B=$ Wienerwald (Hochbichler, 1987); 1,2,3, = Weinviertel/ coppice with standards site $(1=$ Hochbichler, 1987; Krissl and Müller, 1989) site the possibilities are obviously more limited. When establishing the production objective, very differentiated actions are required. A number of reports have shown that annual rate of growth and length of high-quality logs are not only decisively influenced by the silvicultural treatment of the stand (tree) (Oswald, 1979; Spiecker, 1991) but also by the site factor (Schütz and Badoux, 1976; Polge et al, 1979).

Investigations of sites in different regions (Jelem et al, 1965; Lang and Mayer, 1968; Jelem et al, 1974; Anonymous, 1979; Glatzel, 1982) of the growth performances and the structures of stands, partly in combination with economic assessment (Lang and Mayer, 1968; Krapfenbauer, 1983; Pollak, 1983; Hochbichler, 1987; Krissi and Müller, 1989) have constituted the major criteria for the choice of tree species, silvicultural system and type of production objective (table I).

In Austria there are no long-lasting testing areas which could help to set up a silvicultural programme. Due to this, silvicultural programmes have been drawn up taking

Table I. Example of a summary assessment of important biological-ecological features of trees with different site preconditions for growth of high-quality oaks as a basis for optimization of the production objective or production period.

Wienerwald (top height at age $150 \mathrm{yr}: 26-29 \mathrm{~m}$ )

$\begin{array}{lcccc}\text { Mean annual width of tree rings }(\mathrm{mm}) & 2.7 & 2.2 & 1.7 & 1.2 \\ \text { Mean length of branch-free bottom log }(\mathrm{m}) & 7-8 & 9-10 & 12 & 14-15 \\ \text { Formation of water sprouts (-little/+ high) } & - & - & \pm & + \\ \text { Quality of stem (+ good/- bad) } & + & + & + & \pm\end{array}$

Weinviertel (Top height at age $120 \mathrm{yr}: 21-24 \mathrm{~m}$ )

Mean annual width of tree rings $(\mathrm{mm})$ Mean length of branch-tree bottom log $(m)$ Formation of water sprouts (- little/+ high) Quality of stem (+ good/ - bad)

$\begin{array}{cccc}2.8 & 2.2 & 1.7 & 1.3 \\ 5-7 & 6-8 & 10-11 & 12 \\ - & \pm & + & + \\ + & + & \pm & -\end{array}$


into account site-specific growth performance, qualitative-biological timber features and biological-economic considerations regarding cultivation (planting, tending intensity, underplanting, etc) (Hochbichler and Krapfenbauer, 1989: Krissl and Müller, 1989).

The present paper shows that for productive alluvial plain forests a production period of $\approx 100-120 \mathrm{yr}$ and for areas in the submontane regions a production period of (120) 140-160 yr should be determined with a final timber output of 80-100 crop trees per ha and a branchfree bottom bole of 8-12 $\mathrm{m}$. For the most western part of the lower submontane areas, further basic planning on specific sites and silvicultural system has to be carried out.

In the eastern mixed oak forest sites, where coppice with standards system and coppice system dominate, it is above all necessary to find a forest management system, which in relation to the stand site offers the best conditions for achievement of the planned production objective (fig 2).

For vigorous coppice with standards sites (top height 18-24 26-m) a high forest system is suggested with a rotation period of 110-130 yr and a final tree output of 6070 per ha with a knot-free bole of $5-7 \mathrm{~m}$ (Hochbichler and Krapfenbauer, 1987).

On these sites with a suitable stand structure a transformation into stands with "high forest character" seems appropriate (Mayer et al, 1982; Pollak, 1983).

For the drier, less vigorous stand sites (top height 12-17 m) which "compel" a coppice system, overwood-rich or overwood-poor silvicultural systems (rotation time 120-150 yr, knot-free bole, 4-6 m) depending on the soil quality of the site are suggested (Krapfenbauer, 1982; Kriss! and Müller, 1989).

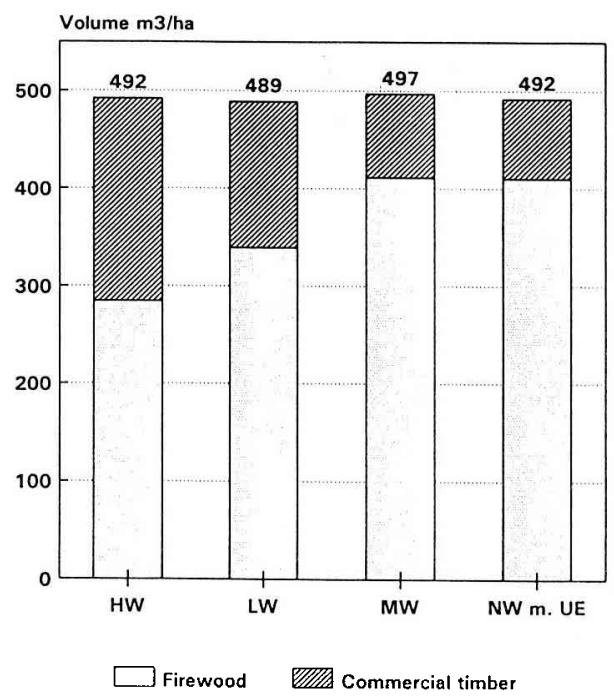

Fig 2. The proportion of firewood and timber for different silvicultural systems on a coppice with standards site and a rotation time of $120 \mathrm{yr}$ (Krissl and Müller, 1989) (HW = high forest system, $L W=$ open stand system; MW = coppice with standards system $30-y r$ rotation of underwood; NW $=$ coppice system with reservations (60-yr rotation of underwood).

On these rather dry sites coppice regeneration has many advantages for generative propagation, such as the protection of the coppice shoot in the same stump and the absence of unfavourable germ and juvenile phases. Additional yield research incorporating a comparative approach to the silvicultural management system of the middle forest stands will be of particular interest in future.

The following study is mostly concerned with the more vigorous forest sites, namely the Wienerwald and the eastern mixed oak forest sites of the Weinviertel. 


\section{SILVICULTURAL TREATMENT}

\section{High forest management}

\section{Planting and natural regeneration}

In the Austrian federal forests regeneration of the stands has been mainly carried out by planting. $4000-6000$ individual plants per ha (2 000-4000 oaks; 2000 hornbeams/limes) have been planted in rows, spaced $2.2 \times 0.5-0.7 \mathrm{~m}$ apart.

Natural regeneration has not played a major role. Today stands are planted in rows with 3500 oaks and 3500 hornbeam/lime, spaced $2.2 \times 0.7 \mathrm{~m}$ apart (Anonymous, 1990). At the middle forest sites planting is carried out with seedlings spaced 2-4 x 0.3-0.7 m apart, but natural regeneration is also important. Because of the high browsing intensity due to far too large a number of game stock, fencing of juvenile stands in some areas is obligatory.

The growth of these stands gives reason to expect a satisfactory quality, with the exception of stands with a wide row spacing of 3-4 m (Krapfenbauer and Hochbichler, 1984).

The intensive planting of oak stands and the promotion of the oaks in previously untreated oak-rich stands indicates that in the future tending young stands and thinning will become more important (fig 3).

\section{Tending young stands}

Numerous surveys on the method of natural artificial regeneration show that thinning from below (negative selection) should end with a thicket. The improvement of the stands with high-quality vital elements in the overstory through positive selection should be encouraged (Leibundgut et al, 1976; Röhrig and Schaper, 1983). The mentioned surveys were an important tool

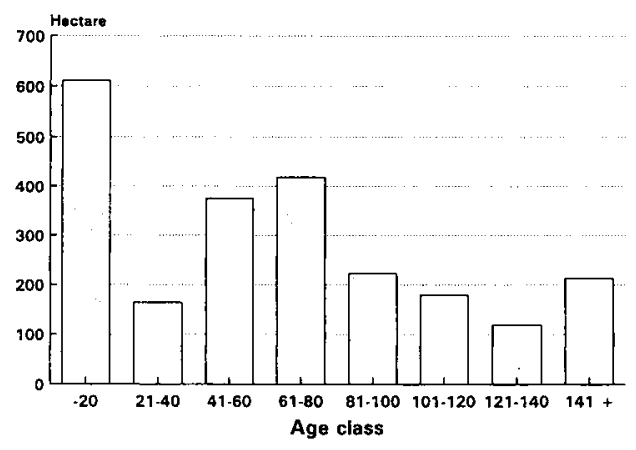

Fig 3. Age classes of oak stands in the Austrian federal forests.

when drawing up tending programmes and coincide with the newer surveys by Mosandl et al (1991) (table II).

Time and intensity of treatment have to be coordinated with the possibilities of the site, individual dynamics of the stands and the following pole stand period. Early interventions show positive reactions in stand climate and secure a vital and stable secondary stand.

Due to the lack of self-pruning within the juvenile oak stands, only an unsatisfactory development is to be expected; therefore pruning of live branches (combined crownand stem-tending) to achieve an improvement is suggested (Hochbichler et al, 1990). As the future quality-performance of the stand is strongly influenced during this, a far more critical assessment of tending necessities and measures should take place in practice.

\section{Thinning}

With the obtention of branch-free bottom logs through pruning a new phase starts, the thinning phase.

The latest findings on the interrelation of age, diameter, crown width (crown length) 
Table II. Tending programme for young oak stands established by natural regeneration in the Weinviertel (rotation time $120 \mathrm{yr}$; mean annual width of tree rings $2.5 \mathrm{~mm}$; crop trees 65 per ha).

\begin{tabular}{|c|c|c|c|}
\hline Age & $\begin{array}{l}\text { Top height } \\
(m)\end{array}$ & $\begin{array}{c}\text { Stem No } \\
\text { (overstory) }\end{array}$ & Treatment \\
\hline & -2 & 6000 & $\begin{array}{l}\text { Elimination of wolf-tree and badly shaped trees, } \\
\text { preferential treatment; sprout pruning }\end{array}$ \\
\hline & $3-6$ & 1600 & $\begin{array}{l}\text { Stem number reduction in the overstory spacing } 3 \mathrm{~m} \text {; } \\
\text { beginning of positive selection; } \\
\text { possible greenpruning to a length with branch-free } \\
\text { bottom log of } 3 \mathrm{~m}(120-150 \text { trees/ha) }\end{array}$ \\
\hline & $7-12$ & & $\begin{array}{l}\text { Favouring of vigorous and well-formed trees spacing } \\
6-7 \mathrm{~m} \text { by removing } 1 \text { or } 2 \text { competitors; } \\
\text { possible greenpruning to a length with branch-free } \\
\text { bottom log of } 6(7)-\mathrm{m} \text { ( } 60-75 \text { trees/ha) }\end{array}$ \\
\hline 30 & $13-15$ & 650 & $\begin{array}{l}\text { Start of selective thinning: } \\
\text { favouring } 60-70 \text { trees/ha (spacing } 10-14 \mathrm{~m} \text { ) }\end{array}$ \\
\hline
\end{tabular}

and the associated control of growth diameter show that quality trees have to be given special support (Oswald, 1979; Schütz and Badoux, 1979; Spiecker, 1991).

Crop selection thinning has been adopted in forest practice. Thinning models, adapted to the production objective and the continuous development of the plus tree, could provide assistance in the decision-making process (fig 4).

The 2 stem number models that are derived from the combined individual tree characteristics (age, diameter, width and length of crowns) by taking into account the planned production objective with the related rotation periods (mean annual width of tree rings from 2.0 and $2.5 \mathrm{~mm}$ ) largely correspond to the stem number models of other authors with the given growth rate. The models clearly show that depending on the production objective and period, heavy thinning measures are necessary in the early pole stage and should end before the second third of the rotation period.

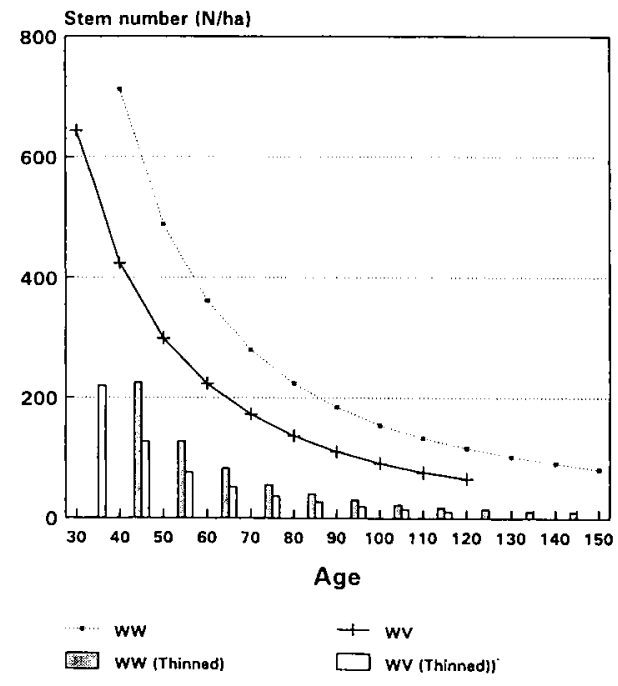

Fig 4. Development of stem number of the remaining and removed stands for thinning models in the Wienerwald (rotation $150 \mathrm{yr}$; mean annual width of tree rings $2.0 \mathrm{~mm}$; crop trees 80 per ha) and Weinviertel (coppice with standards site; rotation $120 \mathrm{yr}$; mean annual width of tree rings $2.5 \mathrm{~mm}$; crop trees 65 per ha) (Hochbichler and Krapfenbauer, 1989). 
Generally only 1 or 2 competitors should be thinned at the same time; therefore an appropriate thinning cycle is necessary. The keeping of "reserve trees" is not advisable.

\section{Coppice with standards system}

Research on different coppice with standards structures clearly shows the need for an objective-oriented, properly planned silvicultural treatment, the most significant consideration being tending of the single tree for sustained cultivation with a balanced distribution of age-classes (diameter size classes) in the overwood with (highquality) timber proportion and tending in the underwood.

"Ideal coppice with standards structures" which have to be maintained or achieved by forest treatment (for example Krapfenbauer, 1982, 1989; Krissl and Müller, 1989) are recognizable by the following:

- a balanced distribution of age classes and an equal distribution of high-quality trees in the overwood;

- favourable sheltering conditions (50)(70)\%), shelter before clear felling;

- sustained upkeep of coppice underwood capability by the appropriate rotation periods (up to a maximum of $30(40) y r$ ),

- sufficient regeneration of the plants with seedlings;

- taking into account of the site-specific potential of soil-nutrients;

- silvicultural treatment to promote natural regeneration.

On the whole, the coppice with standards management in practice offers a broad setting for ecological and economic possibilities.

\section{Regeneration}

The removal of stands by natural regeneration is of utmost importance. The under- wood rotation in association with the sitespecific conditions should not exceed 20$40 \mathrm{yr}$ (maintenance of coppice shoot potential). Apart from the removal of underwood as fuelwood, the regeneration and maintenance of a sufficient amount of oak trees is very important. If natural regeneration by plants of seedling origin is too limited due to an unsatifactory quantity of fruitproducing overwood-oaks, seedlings have to be planted.

\section{Tending}

In the regeneration phase the removal of unwanted tree species such as aspen, birch and willow by simultaneous promotion of mixed tree stands (noble broadleaved tree species) are a main objective. Once again attention should be drawn to the importance of the sheltering circumstances for the regulation of the composition of tree species and growth of the underwood at this age phase (Krissl and Müller, 1989).

From a height of 2-3 m, "thickettending" requires differential action. Stool shoots should be reduced to 2-3 saplings per stool. Particular attention should be given to the removal of the far-reaching saplings, because they could hinder the development of the stower-growing plants of seedling origin.

\section{Treatment of the "plus trees"}

Selection and crown tending (eg greenpruning) are possible at the same time with a sufficient number of well-formed plants of seedling origin for optimal spacing.

With special tending the plus trees can be secured by a balanced development of the crowns and a continuous enlargement of the growing space. With these methods the periodical formation of sprouts after removal of the underwood can be prevented. 
Aside from periodical felling in the overwood, the maintenance of high-quality seed trees and the promotion of the future crop trees starting with the younger ageclasses with uniform spacing is necessary.

\section{Coppice system}

In relation to biomass production as a source of energy (fuelwood), biomass production in the coppice system on sites which are liable to dryness and where coppice regeneration is favoured is increasingly under discussion. Because rotation periods are dependent above all on coppice capability ( $\max 30(40)$ yr) this type of exploitation remains significantly below its optimal yield performance. Further problems (limiting factors) are the result of a rapid decrease in coppice capability and lowered sprouting vitality and disturbance of nutrient circulations through biomass/ nutrient withdrawal (Krapfenbauer, 1989).

\section{REFERENCES}

Anonymous (1979) Waldböden auf wechselfeuchten Standorten mit sekundärer Baumvegetation und ihre Beurteilung im Hinblick auf Baumartenwahl und Bewirtschaftung. Arbeit des Institutes für forstliche Standortsforschung, Univ Bodenkultur, Vienna

Anonymous (1987) Nicht nur Brennholz produzjeren. Bericht über eine Weiterbildungsveranstaltung der niederösterr. Agrarbezirksbehörde in Au/Leithagebirge. Holzkurier (3), 15

Anonymous (1990) Waldbauliche Richtlinien zur Bewirtschaftung des Waldes der Österreichischen Budesforste im Wienerwald. Generaldirektion der Österr Bundesforste, Abt für Forsteinrichtung und Waldbau, Vienna

Buchleitner E (1983) Mikroskopische Untersuungen über die Anatomie des Haustoriums und die Keimung der Eichenmistel (LOranthus europaeus). Diss Univ Bodenkultur, Vienna
Glatzel G (1982) Standortskundliche Untersuungen zur Frage der Bewirtschaftung von Stagnogleystandorten im südöstlichen Österreich. Centralbl Gesamte Forstwes 2, 65-88

Hochbichler E (1987) Standortsbezogene Behandlungsprogramme für die Werteichenproduktion. Diss Univ Bodenkultur, Vienna

Hochbichler E, Krapfenbauer A, Mayrhofer F (1990) Ein Pflegemodell für Eichenjungbestände - Grünastung, eine wirtschaftliche Problemlösung der Wertholzerziehung. Centralbl Gesamte Forstwes107, 1-12

Kraptenbauer A (1983) Eichenmittelwald - Eichenmistelprobleme. Inf schrift zur Exkursion Hochleitenwald, Traun'sches Forstamt Wolkersdorf

Kraptenbauer A, Hochbichler E (1984) Erprobung eines Pflegemodells in Eichenjungbeständen. Central Gesamte Forstwes 3, $172-180$

Krapfenbauer A (1989) Biomassenproduktion und -nutzung zur Energiegewinnung. Centralbl Gesamte Forstwes 2, 89-108

KrissI W, Müller F (1989) Waldbauliche Bewirtschaftungsrichtlinien für das Eichenmischwaldgebiet Österreichs. FBVA Berichte No 40

Leibundgut H, Auer C, Burckhardt RW (1976) Grundlagen der Jungwaldpflege: Ergebnisse zwanzigjähriger Untersuchungen über die Vorgänge der Ausscheidung, Umsetzung und Qualitätsenstwicklung in jungen Eichenbeständen. Ann Rech For Suisse 52 (4), 311 371

Lang $H$, Mayer H (1968) Waldbauliche Grundlagen für die Ejchenwertholzproduktion im nordöstlichen Flysch-Wienerwald. Centralbl Gesamte Forstwes 85 (4), 222-243

Mayer $\mathrm{H}$ et al (1982) Dr Ferdinand Graf Abensberg und Traun. Forschungsauftrag: Der Eichenmistelbefall im Weinviertel. WaldbauInstitut, Univ Bodenkultur, Österr Agrarverlag, Vienna

Mosandl R, El Kateb H, Ecker J (1991) Untersuchungen zur Behandlung von jungen Eichenbeständen. Forstwiss Centralb/ 110, 358-370

Oswald H (1979) Die Durchforstung der Werteichenbestände in Frankreich. In: Begründung und Pflege von Werteichenbeständen. MLU, Stuttgart, No EM-8-80

Polge $H$ (1979) Werteichenproduktion in Frankreich. AFZ 34 (17/18), 430-434 
Pollak M (1983) Grundlagen eines Waldbaukonzeptes für die Dr Paul Esterhazy'sche Forstverwaltung Einsenstadt/Leithagebirge. Dipl Arbeit, Univ Bodenkultur, Vienna

Röhrig E, Schaper C (1983) Über des Ausmaß und die Bedeutung soziologischer Umsetzungen in Eichenjungbeständen. Forstarchiv 54 (1), 3-7

Schütz JP, Badoux E (1979) Ertragsleistung von Jungeichenbeständen in Abhängigkeit von
Standort Mitt d Eidgen. Anst Forstl Versuchswes $55,1-75$

Spiecker H (1991) Zur Steuerung des Dickenwachstums und der Astreinigung von Trauben- und Stieieichen. In: Schriftenreihe der Landesforstverwaltung Baden-Würtemberg, Bd 72

Weilharter W (1991) Wiederaufforstung der Sturmschadensflächen- Chance zur Mischwaldbegründung. Österr Forstzeit (2), 5-7 